ENTREPRENEURSHIP AND SUSTAINABILITY ISSUES

ISSN 2345-0282 (online) http://jssidoi.org/jesi/

2021 Volume 8 Number 3 (March)

http://doi.org/10.9770/jesi.2021.8.3(11)
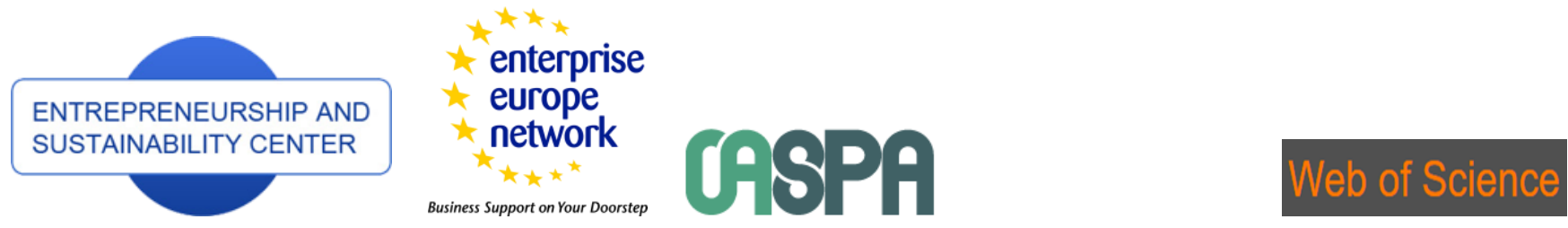

Publisher

http://jssidoi.org/esc/home Clarivate
Analytics

\title{
THE EFFICIENCY EVALUATION OF PUBLIC PROCUREMENT OF MEDICAL EQUIPMENT*
}

\author{
Beata Gavurova ${ }^{1}$, Matus Kubak ${ }^{2}$ \\ ${ }^{1}$ Tomas Bata University in Zlín, Mostni 5139, 76001 Zlin, Czech Republic \\ ${ }^{2}$ Technical University of Kosice, Letná 9, 04200 Košice, Slovak Republic

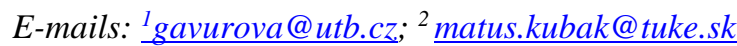

Received 25 October 2020; accepted 22 December 2020; published 30 March 2021

\begin{abstract}
At present, the health systems of many countries face complex challenges even if their priority objectives remain the same - to provide sustainable health systems at the current and the prognostic demographic changes and requirements in a health system. The quality and the efficiency of healthcare delivery and their mutual conformity have been brought to public attention. Similarly, the quality and the efficiency of an entire process depends on the instrumentation and its procurement that represents a significant economic and procedural issue in the healthcare systems for a long time. Many reports of the public procurement processes and research studies declare this fact. The primary aim of this study is to evaluate the public procurement efficiency in the health system by means of the valuation approach, or savings' estimates that are achieved by the public procurement. The savings were defined as a percentage difference between the estimated
\end{abstract}

\footnotetext{
* This research was supported by the Internal Grant Agency of FaME Tomas Bata University in Zlin: RVO/2020: "Economic quantification of marketing processes that focus on value increase for a patient in a process of system creation to measure and control efficiency in health facilities in the Czech Republic".
}
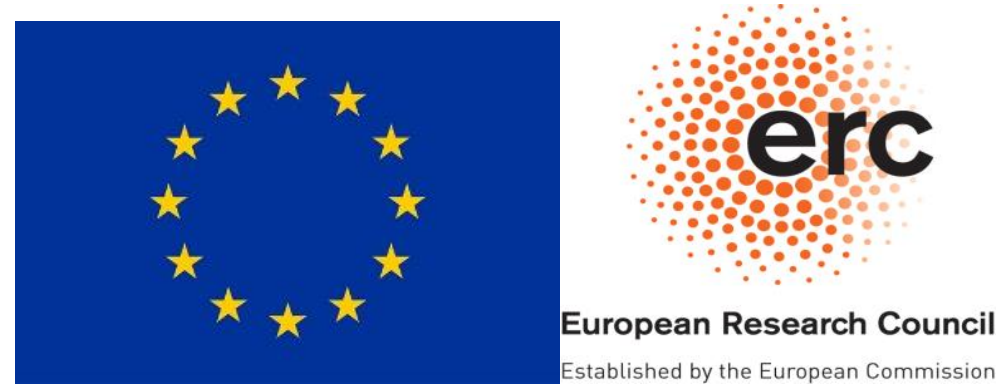


\section{ENTREPRENEURSHIP AND SUSTAINABILITY ISSUES}

ISSN 2345-0282 (online) http://jssidoi.org/jesi/

2021 Volume 8 Number 3 (March)

http://doi.org/10.9770/jesi.2021.8.3(11)

and the final contract price. The secondary objective is to examine an influence of selected variables on a creation of savings in the public procurement process by means of a regression analysis. The researched variables are as follows: time, method, procurement, NUTS level of procurement, Common Procurement Vocabulary Code, number of offers. The analysis results showed interesting findings. The number of offers has a significantly positive impact on the savings. It means that if the number of offers increases by one unit, the savings will increase by $15.6 \%$. Also, time variable (year) has a positive impact on the savings. Consequently, it may be assumed that the public procurement process is improving from a time perspective. It may be partially caused by the fact that a new public procurement legislative has been valid since 2015. The NUTS level has also an impact on the savings in relation to the public procurement. The public procurements which took place at the level of a state were more beneficial as the public procurements at the regional level. Also, the procurement method was statistically significant parameter of a regression analysis. The competition actions together with a negotiation process created higher savings in comparison to tenders. In case of the CPV codes, the most significant savings were achieved in the group of 'various medicinal products'. The study's results provide a valuable knowledge for the creators of policies and a realization of the national strategic plans within the health system. Also, these results support a creation of national and international benchmarks in this area and a networking of international partnerships in the area of a public procurement that focus on a development of methodologies and comparative platforms creation.

Keywords: Public Procurement; Public Procurement Efficiency; Medical Equipment; Patients' Satisfaction; Public Procurement Efficiency Determinants; Savings

JEL Classifications: D20, H32

Reference to this paper should be made as follows: Gavurova, B., Kubak, M. 2021. The efficiency evaluation of public procurement of medical equipment. Entrepreneurship and Sustainability Issues, 8(3), 193-209. http://doi.org/10.9770/jesi.2021.8.3(11)

Additional disciplines: political sciences

\section{Introduction}

In the last decades, the health systems of many countries have solved plenty of complex tasks. The demographic ageing process that is evident in many countries requires proper setting of various active policies in order to sustain the health systems. The ageing European population is more susceptible to numerous chronic diseases that result in an increase of a healthcare demand. Delivering quality health services creates strong fiscal pressures in the economy (Breandle \& Colombier, 2016). Its main reason is a strong technological development and an implementation of innovations into diagnostic and treatment processes. Many international institutions draw attention to significant and constant differences in a health among the countries. Similarly, the differences in a health, that are caused by a different healthcare availability and also various socio-economic factors, systems of the healthcare financing, deployment of health workers, etc., are identified within the particular countries (Ucieklak-Jez \& Bem, 2020; Megyesiova \& Lieskovska, 2018, 2019).

The public sector plays an important role in the processes of the healthcare services' financing. In the two thirds of the EU member states, the public sector finances more than $70 \%$ of the healthcare costs. Consequently, the ageing population creates serious concerns of the sustainability of public finances. The public healthcare expenditures are the largest part, which increases the most when considering the public expenditures. In the future, it is expected that the public healthcare expenditures rate will increase on the GDP. It is also confirmed by the population ageing prognoses by 2060. The main factors that cause this increasing process are as follows: demand for high-quality health services, increasing expectations, and strong technological progress (European Commission, 2020; Briestenský \& Ključnikov, 2019; Kočišová \& Sopko, 2019).

In recent years, there have been evident as fiscal issues, so healthcare efficiency issues within the health systems (Bem et al. 2019). All of the areas of healthcare spending search for the means that would use the resources more effectively (Ucieklak-Jez et al. 2018). As some of the WHO reports state, almost one-fifth of healthcare spending does not contribute to any improvement of population's health, and/or to a minimum extent. Unfortunately, such a 


\section{ENTREPRENEURSHIP AND SUSTAINABILITY ISSUES}

ISSN 2345-0282 (online) http://jssidoi.org/jesi/

2021 Volume 8 Number 3 (March)

http://doi.org/10.9770/jesi.2021.8.3(11)

spending leads to worse health results in some of the cases (European Commission, 2020; Predkiewicz et al. 2019; Stefko et al. 2018).

Therefore, many countries deal with the following issues for a longer period of time - a search for more effective use of resources, or setting the processes in the health systems in such a way that less resources are spent, while a performance of the health systems or health results will not worsen (Stefko et al. 2016). In the European countries, there exist other serious issues of the health systems, such as unequal access to healthcare, fiscal pressures of different departments, corruption, frequent changes of political priorities, lack of information of investments' efficiency into health systems, etc.

One of the key factors of public finance system is an increase of public procurement processes' efficiency. Many countries of the European Union intensively work on a reform of public procurement processes. The main aim of a public procurement is to create an open competition in order to achieve the most effective use of public resources. The Slovak health system belongs to those systems that declare the long-term financial difficulties. The Slovak hospitals represent the weakest segment of the healthcare system. Similarly, the public hospitals still suffer from major losses in spite of the fact that many reforms have been made on cost-effectiveness increase.

The competition rate significantly lags behind the majority of the EU countries even many positive changes have been recently done in the public procurement of the Slovak health system. In Slovakia, a low efficiency of the public procurement processes is influenced by other factors, such as an excessive use of the lowest price criterion in the selection process, a preparation of public procurements without any necessary ex-ante analysis of a purchase planning efficiency, etc. (Nemec et al. 2020). On the other hand, the public procurement processes in the Slovak health system may be improved and more efficient by using the diagnostic and the treatment processes in the health system. Consequently, a higher patient's value may be created from public resources that would also provide the sustainability of public finances and the Slovak health system (Huculová, 2018).

The submitted study, whose aim is to verify the public procurement efficiency in the health system by means of the valuation approach, and/or savings' estimates which are achieved by public procurement, reflects on these facts. The savings are defined as a percentage difference between the estimated and the fiscal contract price. The secondary objective was to examine an influence of selected variables on a creation of savings in the public procurement process by means of a regression analysis. The variables are as follows: time, method, procurement, NUTS level of procurement, Common Procurement Vocabulary Code, number of offers. The analysis's results provide a space for the creation of national and international benchmarking indicators and also for a realization of comparative analyses that are required for the processes of efficiency increase (Triantafillou, 2007).

The study is structured as follows: Introduction focuses on the public finances sustainability and the health systems, which are impacted by the global processes of the demographic ageing. The Research Review (Background of the Study) pays attention to the research studies that deal with the public procurement efficiency, and also their determinants, which are declared in the national and international research studies. The research part of this study is divided into methodological and analytical parts. The methodological part describes the data base and all of the methodological procedures that were used. The analytical part provides the results visualised in the form of the graphs and tables. Both, Discussion and Conclusion of this study, are linked to these results.

\section{Theoretical background}

Many foreign research teams deal with the public procurement efficiency. Their primary aim is to examine the determinants of the public procurement, and also to search for the possibilities that would make these processes more effective. Generally, the contents of these research studies are very heterogenous. However, these studies bring valuable knowledge for the creation of a discussion platform and for the setting of the comparative 


\section{ENTREPRENEURSHIP AND SUSTAINABILITY ISSUES}

ISSN 2345-0282 (online) http://jssidoi.org/jesi/

2021 Volume 8 Number 3 (March)

http://doi.org/10.9770/jesi.2021.8.3(11)

researches. Most of the research studies analyse such factors as corruption, competitiveness and transaction costs that influence the efficiency of public procurement (e.g. Huculová, 2018; Baldi \& Vannoni, 2017; Borowiec, 2017; Ochrana \& Maaytová, 2012; Ochrana \& Pavel, 2013; Vasconcelos, 2021). Other group of studies analyse only particular factors, while there are also such studies that more complexly evaluate the public procurement efficiency. Similarly, such research studies differ from each other depending on the implication type into relevant policies, and/or they bring suggestions for an improvement of existing data bases, or they open new data registers. Grega et al. (2019) verify the main factors that have an impact on the public procurement efficiency in Slovakia, while the authors use the interview method and questionnaires. The questionnaires were created for contracting authorities/entities and suppliers, while 13571 of suppliers and 4300 of contracting authorities participated in the research. Both, suppliers and contracting authorities, explicitly confirmed that the most important factors, which cause non-efficiency in the public procurement are: excessive bureaucracy and corruption or other ethical shortcomings. The results also show that the insufficient competition and the excessive use of the lowest price criterion for selecting winning bids add further inefficiencies. The largest savings were achieved between 6 and 8 bidders. In conclusion, the authors state that the e-auctions generally produce larger savings than more traditional methods, but the Slovak procurement procedures are costly, compared to most other EU states. The study provides valuable subjects for the policies' creators that focus on the improvement of the public procurement processes in order to achieve their higher efficiency.

There are also studies that present new collaborations and partnership networks as the tools for efficient public procurement processes, and simultaneously, improving efficiency of investment processes that are linked to the projects of the public procurement. Many studies examine programs of green public procurement. These topics are related to the global trends of environmental protection that need to be interconnected with the efficiency processes. In the study of Berezin et al. (2018), the authors state that the implementation of the public-private partnership (PPP) improves public and municipal property in the EU countries. The study aims at the classification outline of the countries according to the probability of success in the PPP implementation. The study presents a significance of a new method that should be based on the indicators' system by means of which it should evaluate a quality of the institutional environment, experiences with the project realization, state's preparedness, and also institutional sphere on the efficient implementation of the PPP projects. The authors also suggest that the role of a state plays an important role in the strengthening of the PPP projects' realization by means of the financial sphere. It will also support a creation of various mechanisms that would attract private investments to socially significant public projects. Similarly, Nemec et al. (2020) indicate an insufficient level of a competitiveness as the primary factor of an insufficient efficiency of the public procurement. In the study, the authors declare that the level of a competitiveness in Slovakia significantly lags behind the majority of the EU countries. Low level of a competitiveness has a direct impact on the public procurement efficiency, which is frequently evaluated by comparing the estimated value to the competitive pricing. The authors analysed data from 2141 public procurements in the period 2014 - 2019. In conclusion, the authors confirm that a higher number of offers in the Slovak health system generates a lower final price. In average, the number of offers is two, but almost in one third of the competitions, the health facilities received only one offer. Grega (2018)identifies and analyses in detail the main factors that determine the public procurement efficiency in Slovakia by performing a vast primary and secondary research. The author determines bureaucracy as the most important factor of the efficiency in the public procurement processes on the basis of the research. The second factor is a frequent change of a legislative, and the third factor is an insufficient ethics and morality on the awarding authorities and/or the contracting authorities' sides. Both, corruption and insufficient competitiveness, that are presented by joining a small number of suppliers into the public procurement, represent the fourth most important factor.

Thematically similar studies were realized in abroad, and their results create an interesting discussion platform for this team of authors. For instance, Grzyl et al. (2018) performed their research in order to verify to what extent the Polish contracting authorities use a selection option of many criteria to evaluate the offers. The authors analysed 500 notices on work procedures conducted in open and restricted tenders in Poland and 500 tenders in open and 


\section{ENTREPRENEURSHIP AND SUSTAINABILITY ISSUES}

ISSN 2345-0282 (online) http://jssidoi.org/jesi/

2021 Volume 8 Number 3 (March)

http://doi.org/10.9770/jesi.2021.8.3(11)

restricted proceedings in five selected EU countries. The results of the comparative analysis show many interesting conclusions. The price, as a decisive criterion in selecting an offer, has both, advantages and disadvantages. The following may be supported by using the price criteria and others: increase in the efficiency of public spending, a better definition of the basic characteristics of a product and a better preparation of contract's subject description, granting the particular characteristics of a product in the context of innovations, a limited impact on the environment, etc. However, the authors confront the use of many criteria in the public procurement with increasing costs of a company, a complex procedure for offers' evaluation and other risks.

Kozik and Karasińska-Jaśkowiec (2016) focus on the evaluation of the public procurement processes in the context of environmental protection. The subject of the public procurement is infrastructure in the selected Polish municipalities. In the analyses, the authors use the following criteria: time of the public procurement realization (2009-2015) and co-financing of the contract from the EU funds. Similarly, the authors examined the environmental aspects of planned investments in the contracts by detailed analysis of the environmental criteria, and also legislative acts adopted in Poland and Europe. In conclusion, the authors declare that the legislative acts do not represent any obstacle in the awarding process that has an impact on the environment. The authors also emphasize a consistency of the legislative acts at both, national and international levels.

The study by Fuentes-Bargues et al. (2018) has a sector orientation to education system. As the authors confirm the universities have a significant role for the public institutions as they make plenty of purchases and financial procedures on daily basis. The study presents the research results which reflect the analysis of 316 procedures that were collected and analysed from the calls for tenders made by the Spanish public universities between 2016 and 2017. Also, the environmental criteria, which were analysed according to the sub-sectors, the geographic scope, and the project's budget, have an important role. The study's results clearly declare a low use of environmental criteria in the contracts that are awarded by the Spanish public universities. The conclusions of the study provide multiple implications for the policies' creation, such as the fact that the environmental policies of the universities should be a part of their institutional policies.

The research study by Grzyl and Siemaszko (2018) is linked to the Europe 2020 strategy, which also emphasizes an effective use of natural and ecological resources. Both analyses, Life Cycle Assessment and Life Cycle Cost, should form a basis of the decision-making by awarding entities according to the authors. Thus, the authors present the advantages of their use. The authors analysed 350 of selected public procurement procedures that were realized in 2017 in Poland. In the analytical processes, there were examined the types, the average weights and a frequency of application of non-price criteria for the selection of the best offer in practice. In conclusion, the authors expressly declare a convenience of using the following analyses, Life Cycle Assessment and Life Cycle Cost. Both analyses are considered as the tools for determining a real value of the contracts' subject. However, the environmental requirements are obligatory in most of the cases of the contracts' realization. The use of non-price criteria further remains a difficult task in the public procurement processes and their importance will even increase in the future.

Grzeszczyk and Czajkowski (2017) draw attention to different specificities of the projects that are co-financed from the EU funds and commercial projects. The projects that are co-financed from the EU sources are oriented to the environmental economic and social advantages for a society. Therefore, it is important to research numerous factors that influence the public procurement processes of the EU projects. Also, the authors use the European projects observation, comparative study, literature and documentary analysis in order to highlight the structure and the seriousness of the problems in these types of projects. The project management and the pressures on the development of methods that would eliminate the risks of the mistakes in these projects are brought to the attention. However, one serious mistake may lead to the loss of all of the subsidies and subsequently, it may threaten a realization of an entire project. Consequently, the authors emphasize a necessity of the processes' improvement for the purchases and the implementation of co-ordinated purchase activities. 


\section{ENTREPRENEURSHIP AND SUSTAINABILITY ISSUES}

ISSN 2345-0282 (online) http://jssidoi.org/jesi/

2021 Volume 8 Number 3 (March)

http://doi.org/10.9770/jesi.2021.8.3(11)

The study by Weszl et al. (2019) examines an importance of incorporating new criteria in purchasing the medical devices. The Patient Reported Outcome Measures (PROMs) may serve as a significant value instrument for the producers, which also complete safety and performance metrics. The PROMs also represent a competitive instrument. The authors examined the PROMs within 12 selected groups of instruments within many developed countries. The analyses' results show that the use of the PROMs increases. It may be caused by a demand of the buyers who prove the value of the device. However, this trend differs in other EU countries.

The authors, Šumpíková and Ďurčeková (2019) realized an interesting comparative analysis that aims at researching the extent of the use of external law services in the public-procurement review process by procuring authorities and proposers in the Slovak Republic and the Czech Republic. The study's results show that while the use of the external law firm may lead to a higher success rate of the review process on the side of a procuring authority, the same does not apply to proposers. The same results are confirmed by the study of the Czech authors, Ochrana and Maaytová (2012). The study by these authors focuses on the public procurement efficiency in the Czech Republic. Also, it identifies a low transparency and an insufficient resistance to a corruption as the main issues. In general, the study provides multiple implications into the policies' creation that refer to a formation of a transparent public procurement system without any corruption. Similar findings may be found in the study by Ochrana and Pavel (2013).

The corruption in the public procurement is examined in more details in the studies by Fazekas and Toth (2016) and Fervarda et al. (2017). Both studies prove that accurate and profoundly structured data are necessary for a creation of the quality analytical framework. It is also confirmed in the study by Coviello and Mariniello [33] that aims at verifying how publicizing of a public procurement auction causally affects an entry and the costs of a procurement. The authors run a regression discontinuity design analysis on a large database of the Italian procurement auctions.

Oruezabala and Rico (2012) also point to the importance of compliance with new sustainable regulations and to look for suppliers who are able to provide a sustainable offering. They carried out research in the 15 French hospitals through semi-structured interviews. The results of the research enabled the authors to formulate an interesting process trajectory: the sustainable expectations of public buyers from global key providers and the fact that sustainable procurement impacts the relationship by creating new rules. Building on these results, managerial implications are suggested. In addition to the "sustainable public procurement" term, also the responsible public procurement term is often mentioned. The "responsible public procurement" term is a part of the good governance which is a process whereby organizations meet their needs for goods, service, works, and utilities in a way that achieves value. It is stated in the study by Plaček et al. (2020) who describe the basic elements of modern public procurement in detail: value for money, transparency, fairness, and good governance.

Mudyarabikwa et al. (2017) examined the potential of public-private partnership (PPP) activities and their importance in improving the procurement processes of physicians in primary healthcare. The main goal of PPP was to improve the quality of healthcare and patient satisfaction. The authors carried out the qualitative analysis based on the 25 interviews with public sector staff and private sector managers. Results of the analyses clearly confirm that PPP bring the expected health benefits. Fuentes-Bargues et al. (2019) dealt with the issue of green public procurement at the regional level too. The development of green public procurement also makes it possible to summarise experiences and to design areas that are possible to improve. The authors focused on the selected Spanish region and they analysed a total of 957 procedures in the period of the years 2016 to 2017. The results of the study show the following facts: the use of environmental criteria is $19.7 \%$ and the average weight is 4.1 out of 100. The differences in the use of environmental criteria are also determined by the sectors. 


\section{ENTREPRENEURSHIP AND SUSTAINABILITY ISSUES}

ISSN 2345-0282 (online) http://jssidoi.org/jesi/

2021 Volume 8 Number 3 (March)

http://doi.org/10.9770/jesi.2021.8.3(11)

The results have several implications for policy-making as well as suggestions how to improve the environment public procurement through the creation of targeted plans.

In addition to the research teams, several institutions have examined the effectiveness of public procurement processes in Slovakia dealing with system efficiency and transparency. For instance, Dančíková and Zachar (2012) analysed the public procurement of hospitals in the years 2009 to 2012. The authors found that public procurement of hospitals is characterised by a low number of tenders submitted. In a $54.6 \%$ share of tenders, only one bidder submitted a bid. Average number of bids in hospital tenders is 1.7, while in other sectors in the same period there were almost 3 bids per tender. This means that the health sector is exposed to lower competition in public procurement between suppliers. More than a half of the procured volume of hospitals was provided by only the 13 companies. And just a $21 \%$ share of 2,771 public procurements were announced by an electronic auction. E-auctions are used in healthcare especially for contracts with lower contracted price. These findings suggest that a space to increase efficiency in healthcare of the Slovak Republic is large and therefore, the preparation of active policies and extensive institutional collaboration will be important in economic as well as legal field.

\section{Materials and Methodology}

Our dataset consists of public procurements that took place in healthcare sector from 2014 to 2019. Data was downloaded from registers of the Office for Public Procurement of Slovak Republic. For every public procurement, we were able to collect data about:

- Year when public procurement took place,

- Procurement method,

- NUTS level of the procurement,

- Common procurement vocabulary code,

- Number of bids,

- Estimated value of the contract,

- Competitive price.

Year when public procurement took place is a categorical variable which indicate the date of the public procurement. Dataset comprises 6 years and the distribution on observations is following: year 2014 - 431, year 2015 - 332, year 2016 - 383, year 2017 - 209, 2018 - 287 and year 2019- 499.

Procurement method is the categorical variable which tell us how public procurement was done. There were only two types of procurement in the dataset. Tender was used in 223 cases, thus $10.4 \%$ of the total cases and the competitive procedure with negotiation which was used in 1918 cases, thus $89.6 \%$ of total cases.

The NUTS code is the categorical variable capturing the level of common classification of territorial units on which the public procurement took place. According to Eurostat NUTS 1 represents the major socio-economic regions, thus national level. NUTS 2 represent basic regions for the application of regional policies, in case of Slovakia it is Eastern Slovakia, Central Slovakia and Western Slovakia. NUTS 3 represent small regions for specific diagnoses, in case of Slovakia we distinguish eight self-governing regions. In our dataset, $1.5 \%$ of the public procurements took place at the NUTS 1 level, $15.5 \%$ at the NUTS 2 level and 83\% at the NUTS 3 level.

Common procurement vocabulary code is the classification system for public procurement that enables to standardize the references used by contracting authorities and entities to describe procurement contracts. We use CPV codes four digits structure, thus distribution among classes. The distribution of the number of public procurement for the whole period depending on the common procurement vocabulary code is shown on figure 1 . 


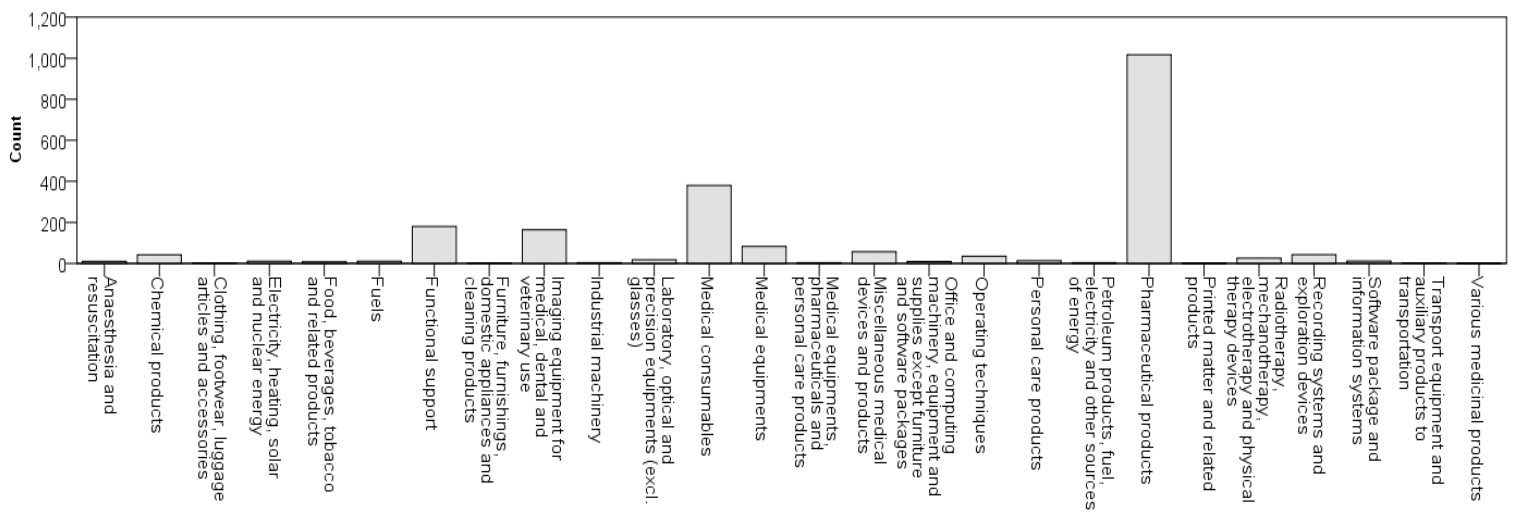

Figure 1: Distribution of the number of public procurements

Number of bids is the scale variable indicating how many bids were received during the bidding process. Number of bids distribution is shown in figure 2. Most public procurements, $36.5 \%$, were done with only one bid. Pubic procurements with two and three bids were observed in $24.8 \%$, respectively in $24 \%$ of cases.

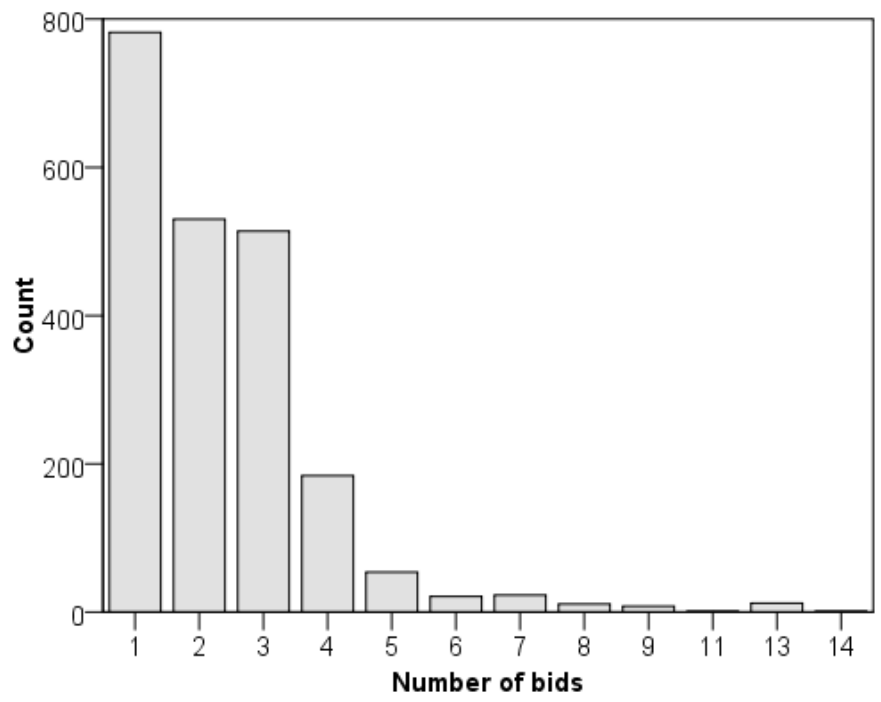

Figure 2: Number of bids per public procurement

Estimated value of the contract is the price of the contract estimated by entity that launches competition, respectively create a query. Competitive price is the bid that won the public procurement competition, thus final price of the public procurement competition.

\section{Methodology}

In presented research we use the most commonly used approach for measuring the efficiency of public procurement, thus the difference between estimated value of the contract and the competitive price. This approach seems to be the most transparent and fastest way to evaluate the efficiency of public procurement. The inconvenience of this approach is the estimation of the estimated value of the contract. For this reason, some opinions favours to compare the competitive price of the contract with the market price of the purchased products. 


\section{ENTREPRENEURSHIP AND SUSTAINABILITY ISSUES}

ISSN 2345-0282 (online) http://jssidoi.org/jesi/

2021 Volume 8 Number 3 (March)

http://doi.org/10.9770/jesi.2021.8.3(11)

But use of market price has also its limits. The biggest counterargument the market price use is fact, that market price not always available and clearly determinable, especially in case of information systems, legal and advisory services, large construction project and last but not least, services as such. Because of abovementioned facts and with respect to fact that our dataset includes 2141 observation, we have accepted to use the difference between estimated value of the contract and competitive price, as this approach is widely used in case of large datasets.

While comparing the estimated value of the contract and its final competitive price, three possible outcomes are possible. Savings are positive if the estimated value of the contract is higher than the final price of the competitive price of the purchased goods. Savings are null if the estimated value of the contract is equal to the final price of the goods being purchased. Savings are negative if the estimated value of the contract is less than the competitive price of the goods being purchased. All prices were without VAT. Saving expressed in percentage are calculated as follows:

$$
\text { Saving }=100-\left\{\left(\frac{\text { Final price }}{\text { Estimated price }}\right) x 100\right\}
$$

To determine the main effect of abovementioned variables on achieved savings we run generalized linear model with following equation:

$$
\text { Saving }=\beta_{0}+\beta_{1} \text { Procurement method }_{i}+\beta 2 \text { NUTS }_{i}+\beta_{3} \text { CPV code } \text { C }_{i}+\beta_{4} \text { Number of offers }_{i}+\beta_{5} \text { Year }_{i}+\varepsilon_{i},
$$

where Saving is the continuous variable indicating the size of the saving/loss achieved by public procurement. Procurement method is the categorical variable which indicates the method the public procurement was done: tender or competitive procedure with negotiation. NUTS code is categorical variable indicating the level on which the public procurement too place - national, or regional. CPV code is categorical variable indicating the class of common procurement vocabulary that public procurement concerned. Number of offers is scale variable which indicated how many offers was bidders entered the process of public procurement. Year is variable that indicates the year in which the public procurement took place.

\section{Analysis}

The distribution of saving is shown on the figure 3 . We note from the figure 3 that savings are normally distributed around zero and right skewed.

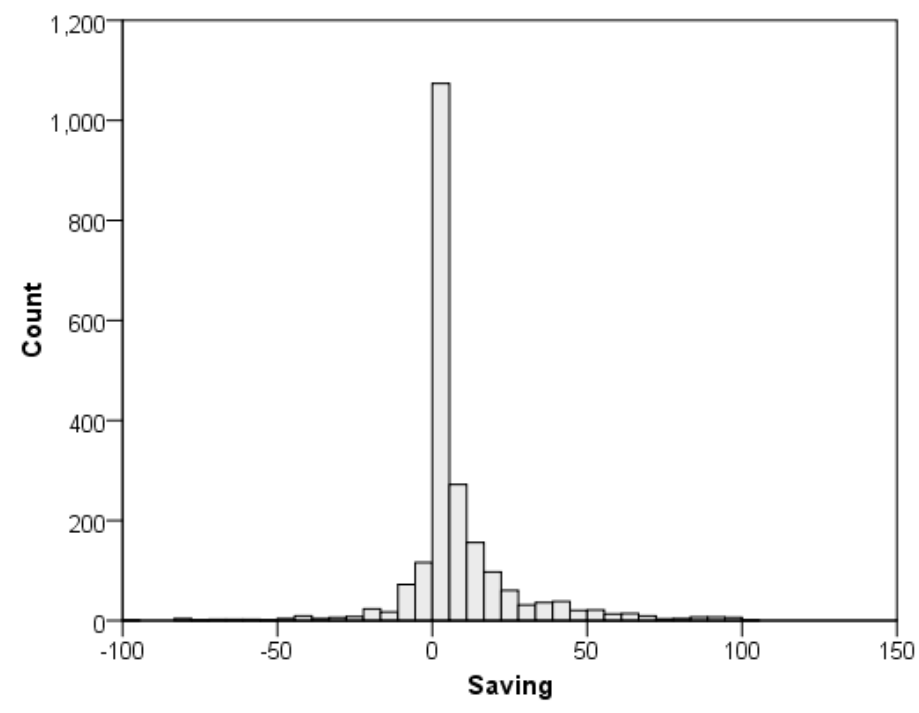

Figure 3: Distribution of saving 
Average saving by CPV class is shown on the figure 4 . We note that highest average savings in healthcare sector can be find in the class of Various medical products, Printed matters and related products, Furniture, furnishing, domestic appliances and cleaning products, Food, beverages, tobacco and related products, Chemical products and Medical equipments. On the other hand, lowest, resp. negative savings are observed in classes of Fuels, Clothing, footwear, luggage articles and accessories, Functional support, Medical equipments, pharmaceuticals and personal care products.

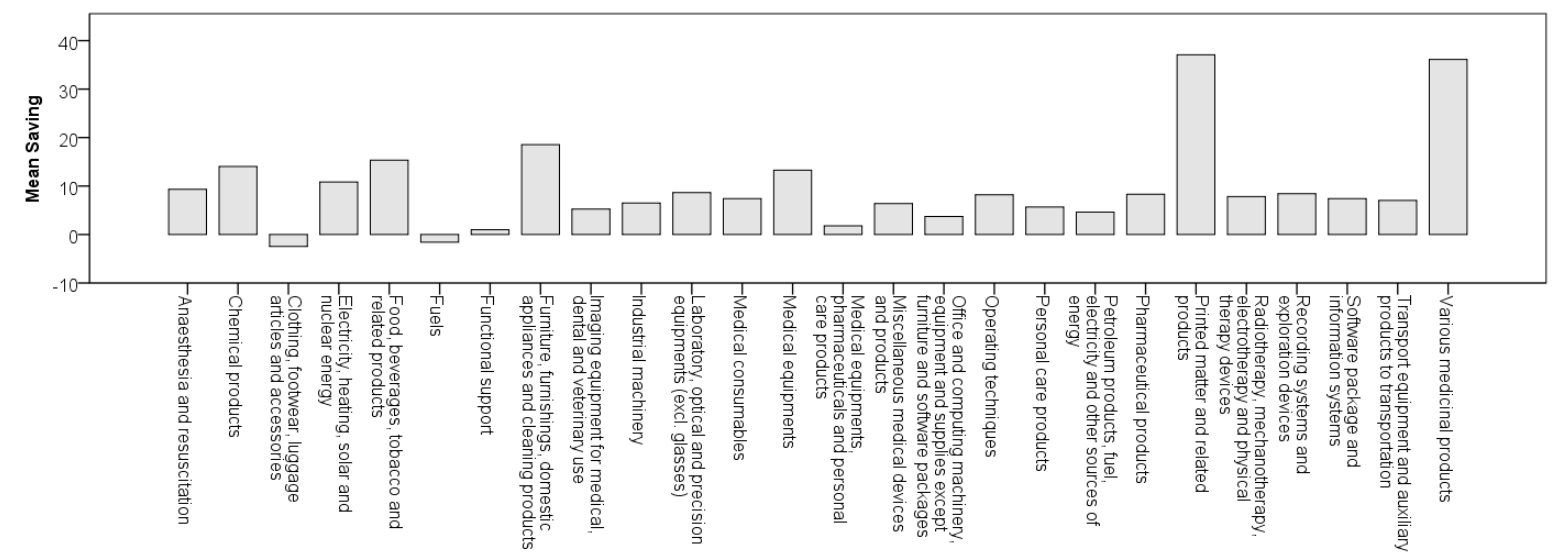

Figure 4: Distribution on savings by CPV class

Test of model effects for regression analysis is shown in table 1. We note that all considered variables have some discernible effect on the dependent variable, as, according to $\mathrm{p}$ values, we are able to reject null hypothesis of zero effect significance of explanatory variables.

Table 1: Tests of Model Effects

\begin{tabular}{|c|c|c|c|}
\hline & Wald Chi-Square & df & Sig. \\
\hline (Intercept) & 7.887 & 1 & .005 \\
\hline NUTS code & 5.996 & 2 & .050 \\
\hline Number of offers & 128.492 & 1 & .000 \\
\hline Year & 7.888 & 1 & .005 \\
\hline
\end{tabular}

Dependent Variable: Saving

Model: (Intercept), Procurement method, NUTS code, CPV code, Number of offers, Year

Subsequently we run Omnibus test, where hypotheses are following.

$\mathrm{H}_{0}$ : Suggested model is not significantly suitable to the data.

$\mathrm{H}_{1}$ : Suggested model is significantly suitable to the data.

Omnibus test Likelihood Ratio Chi-Square is 195.445 on 30 degrees of freedom, with p value <.001, thus we reject null hypothesis that involve the idea that explained variance in a set of data is significantly smaller than the unexplained variance.

Regression analysis results are in table 2. In case of CPV code, we present only classes where regression coefficients are statistically significant. Number of offers has positive impact of savings. It means, that with augmentation of number of offers, saving are significantly rising. Time, thus year has also positive impact on savings. We can outline the finding that public procurement process has improved over time. It can be also partially caused by the fact, that in 2015 , the new public procurement legislative was established. NUTS level has 
ENTREPRENEURSHIP AND SUSTAINABILITY ISSUES

ISSN 2345-0282 (online) http://jssidoi.org/jesi/

2021 Volume 8 Number 3 (March)

http://doi.org/10.9770/jesi.2021.8.3(11)

also impact on savings in context of the public procurement. The conclusion here is that the lover level of territorial administration, the significantly higher saving is. Contrary, if the public procurement is done on national level, the savings are significantly lower. Procurement method is also statistically significant parameter of the regression analysis. The conclusion here is that Competitive procedure with negotiation create higher savings if compared to Tenders. In case of CPV code analysis we have chosen the class of Various medicinal products as a contrast variable, whereas in this class the highest average savings are observed (see figure 4). As written above, we present results only for statistically significant CPV classes. We note that in contrast to Various medicinal products, the lowest savings are achieved in class of Fuels, Petroleum products, fuel, electricity and other sources of energy and Clothing, footwear, luggage articles and accessories, Functional support, Pharmaceutical products and Electricity, heating, solar and nuclear energy.

Table 2: Parameter Estimates

\begin{tabular}{|c|c|c|c|c|c|c|c|c|}
\hline \multirow[t]{3}{*}{ Parameter } & \multirow[t]{3}{*}{ B } & \multirow[t]{3}{*}{ Std. Error } & \multirow{2}{*}{\multicolumn{2}{|c|}{$\begin{array}{l}99 \% \quad \text { Wald } \\
\text { Confidence Interval }\end{array}$}} & \multirow{2}{*}{\multicolumn{2}{|c|}{ Hypothesis Test }} & & \multirow[t]{2}{*}{$\operatorname{Exp}(B)$} \\
\hline & & & & & & & & \\
\hline & & & Lower & Upper & $\begin{array}{l}\text { Wald } \\
\text { Chi- } \\
\text { Square }\end{array}$ & df & Sig. & \\
\hline (Intercept) & -1205.3 & 429.5644 & -2047.265 & $-\overline{363.403}$ & 7.873 & 1 & .005 & .000 \\
\hline Number of offers & 2.749 & .2425 & 2.273 & 3.224 & 128.492 & 1 & .000 & 15.622 \\
\hline Year & .598 & .2130 & .181 & 1.016 & 7.888 & 1 & .005 & 1.819 \\
\hline \multicolumn{9}{|l|}{ NUTS level } \\
\hline NUTS 1 & -4.990 & 3.2150 & -11.291 & 1.311 & 2.409 & 1 & .121 & .007 \\
\hline NUTS 2 & -1.905 & 1.1343 & -4.128 & .319 & 2.819 & 1 & .093 & .149 \\
\hline NUTS 3 & $0 \mathrm{a}$ & . & . & . & . & . & . & 1 \\
\hline \multicolumn{9}{|l|}{ Procurement method } \\
\hline $\begin{array}{l}\text { Competitive procedure with } \\
\text { negotiation }\end{array}$ & 2.152 & 1.2852 & -.367 & 4.671 & 2.805 & 1 & .094 & 8.606 \\
\hline Tender & $0^{\mathrm{a}}$ & . & . & . & . & . & . & 1 \\
\hline \multicolumn{9}{|l|}{ CPV code } \\
\hline $\begin{array}{l}\text { Clothing, footwear, luggage articles } \\
\text { and accessories }\end{array}$ & -37.048 & 20.5034 & -77.234 & 3.138 & 3.265 & 1 & .071 & $8.133 \mathrm{E}-17$ \\
\hline $\begin{array}{l}\text { Electricity, heating, solar and nuclear } \\
\text { energy }\end{array}$ & -27.252 & 18.5578 & -75.054 & 20.549 & 2.157 & 1 & .142 & \\
\hline Fuels & -37.426 & 18.5567 & -73.796 & -1.055 & 4.068 & 1 & .044 & $5.575 \mathrm{E}-17$ \\
\hline Functional support & -30.375 & 17.8049 & -65.272 & 4.522 & 2.910 & 1 & .088 & $6.429 \mathrm{E}-14$ \\
\hline $\begin{array}{l}\text { Office and computing machinery and } \\
\text { software }\end{array}$ & -33.299 & 18.7212 & -69.992 & 3.394 & 3.164 & 1 & .075 & $3.456 \mathrm{E}-15$ \\
\hline $\begin{array}{l}\text { Petroleum products, fuel, electricity } \\
\text { and other sources of energy }\end{array}$ & -34.228 & 19.8565 & -73.146 & 4.690 & 2.971 & 1 & .085 & $1.364 \mathrm{E}-15$ \\
\hline Pharmaceutical products & -29.241 & 17.7571 & -64.044 & 5.562 & 2.712 & 1 & .100 & $1.999 \mathrm{E}-13$ \\
\hline Various medicinal products & $0^{\mathrm{a}}$ & . & . & . & . & . & . & 1 \\
\hline (Scale) & $\begin{array}{l}314.590 \\
\mathrm{~b}\end{array}$ & 9.6151 & 290.773 & 340.358 & & & & \\
\hline
\end{tabular}

\section{Discussion}

Health is a fundamental value in life of every one person. The basic determinants of health include access to healthcare, quality of healthcare, quality of the environment and physiological-psychological preconditions of an individual. A government can influence the quality and availability of healthcare through an active health policy. It creates a system of laws, standards, regulations and cooperation of the health system institutions to ensure all necessary healthcare-related processes. A provision of healthcare is one of the specific services within which healthcare staff and non-medical staff provides medical services to the patient. As healthcare represents a dynamic 


\section{ENTREPRENEURSHIP AND SUSTAINABILITY ISSUES}

ISSN 2345-0282 (online) http://jssidoi.org/jesi/

2021 Volume 8 Number 3 (March)

http://doi.org/10.9770/jesi.2021.8.3(11)

process which the demands and expectations of patients change in, its management requires ensuring compliance in several medical, technical and economic dimensions (Predkiewicz et al. 2019; Stefko et al. 2018). The provision of health care is carried out within the framework of the legislation of each country and the restrictions caused by the economic capabilities of the healthcare provider. There is often a disproportion between patient requirements for the service and financial resources that hospitals do not have and they cannot obtain them. Hence, in the recent years, health systems have been cover a search for opportunities for savings throughout the healthcare system and transparency of resources spent on service performed (Triantafillou, 2015; Borowiec, 2017; Grega et al. 2019).

Public procurement plays an important role in this process. It is a strategic tool that every European Union member state possesses in the system of the economic policy tools. The basis of public procurement is open competition in order to achieve the most efficient use of public financial resources. Many countries have implemented several reforms to improve public procurement processes in recent years [38]. Despite the positive results, there is still a much room for enhancement. Available research studies declare insufficient use of strategic procurement opportunities. As many as a $55 \%$ share of procurement procedures use the lowest price as the sole criterion for evaluating tenders (European Commission, 2017).

The most economically advantageous offers are selected on the basis of principles and cost-effectiveness criteria, which it is also possible to take into account social, environmental and innovative criteria within. Availability criteria or various qualitative criteria are still not sufficiently applied (Nemec et al. 2020a; Grega et al. 2019; Nemec et al. 2020b). Procurement processes are often considered to be rather an administrative procedure, which public authorities purchase the products, works or services necessary for their activities through. Clear and consolidated data on public procurement are not yet available and there is also no consensus within the European Union on which data to collect and for what purpose (European Commission, 2017).

The European Commission also criticises the position of some European Union member states that their central authorities are unable to indicate the exact amount of public procurement expenditure in their country despite the large financial amounts involved in this process (European Commission, 2017). This puts pressure on improvement of public revision and the development of effective data-based policies as well as improved budgetary revision. Innovation is a very important aspect of public procurement processes and thus, it is an important determinant in improving the quality and efficiency of treatment and diagnostic processes in the healthcare system. There are also many barriers to innovation as evidenced by several studies (Nemec et al. 2020a; Berezin et al. 2018; Šumpíková \& Ďurčeková, 2019).

A creation of innovative partnerships can solve this problem too (Berezin et al. 2018; Mudyarabikwa et al. 2017). Also, the digital transformation of public procurement, which is currently assessed as slow and insufficient, is important. Despite the simplification of the European Union rules in the year 2014, many countries criticise the persistence of overly complex public procurement procedures and excessive administrative burdens. This consistent fact affects the standardization of procedures and the professionalization of public procurement (European Commission, 2017).

Many healthcare institutions also have a critical view of the current situation in a field of public procurement in Slovakia, as for instance SK-MED Association, based on the real practice of the medical institutions and their suppliers. As stated in their study, public procurement generalizes patients' clinical status and it does not take into account its specific attributes (SK+MED, 2020).

For patients with a clinical condition, where the use of standard medical devices is not possible, the acquired devices has to be usable and suitable for specific medical purposes. Providers often tend to use inappropriate material for the purpose of financial disputes and the elimination of special administrative procedures required by 


\section{ENTREPRENEURSHIP AND SUSTAINABILITY ISSUES}

ISSN 2345-0282 (online) http://jssidoi.org/jesi/

2021 Volume 8 Number 3 (March)

http://doi.org/10.9770/jesi.2021.8.3(11)

the health insurance companies. Therefore, for a certain group of patients, such a healthcare service is more expensive and hence, it may be unavailable due this fact. Public procurement can also indirectly prevent the use of innovative methods in the treatment process (SK+MED, 2020).

Patients' needs should not be considered in a standardised way. Public procurement as a process in the current or proposed legislative form does not allow to assess the price of treatment in terms of total costs, but it only takes into account the price of the material used. At the present time, the main evaluation criterion in public procurement is price usually (Grega et al. 2019; Nemec et al. 2020).

Neither the current law nor its proposed amendment defines price as a parameter in more detail. Given the importance of the quality criterion, which is very closely linked to the price parameter, it is significantly important that the price in healthcare is assessed as a parameter in terms of total costs in the long term and not as a partial cost in a single procurement. Only then, it is possible to evaluate the effectiveness of the healthcare provided in the diagnostic or treatment process. If only the price is applied in public procurement processes in healthcare, there is a risk that in the end, the total costs may be even higher as they may increase due to various shortcomings of the procured goods. If the healthcare provider procures medical devices through public procurement that can only be used in standard treatment, then the treatment of patients will not be in a line with the latest medical science knowledge in the particular field (SK+MED, 2020).

In order to determine the real state of the efficiency of public procurement processes for medical devices for the period of the years 2014 to 2019, we performed an analysis of the data obtained from the national registers of the Public Procurement Office of Slovakia. We focused on the use of so-called value approach through an estimation of the savings achieved by public procurement. We examined the impact of the selected variables on the creation of savings in the public procurement process through regression analysis. The variables examined are: time, procurement method, NUTS level of procurement, common procurement vocabulary code, and number of tenders. The results of the analyses revealed the interesting findings. The number of offers had a significant positive impact on savings. This means that with an increase in the number of bids by one unit, the savings are increased by $15.6 \%$. The time variable (year) also had a positive effect on the savings. It can be stated that the public procurement process has been improving in the recent period. This may be partly due to the fact that the new public procurement legislation was introduced in 2015. The NUTS level also has an impact on the savings in public procurement. Public procurement at the state level is more advantageous than one at the regional level. The procurement method is also a statistically significant parameter of the regression analysis. The competitive negotiated procedures create the significantly higher savings compared to the tenders. In the case of CPV codes, the most significant savings are achieved for "different drugs". The limitation of our research is caused by an inaccurate input of public procurements parameters by authorities' which are in charge of public procurements information disclosure.

These evaluations represent the valuable findings for policymakers and to ensure a transparent public procurement system as well as for increasing its efficiency. It is also important to confront these results with many institutions that cover suppliers of medical devices and equipment and thus, to create innovative partnerships not only in public procurement processes but also in technological development as manufacturing innovators can provide valuable information for health technology assessment that should be closely linked to public procurement processes in the healthcare sector (Huculová, 2018; Kiselova Bilekova et al. 2018; Zavadil et al. 2020; Petruželka \& Barták, 2019).

The absence of this link can result in many negative facts, which will be related to the preferred use of price as the most important criterion in the entry stages of public procurement in healthcare. If we would like to ensure the effectiveness of public procurement processes in order to gain more value for the patient and at the same time to ensure the quality and safety of treatment and a higher quality of life of the patient, individual parameters entering 


\section{ENTREPRENEURSHIP AND SUSTAINABILITY ISSUES}

ISSN 2345-0282 (online) http://jssidoi.org/jesi/

2021 Volume 8 Number 3 (March)

http://doi.org/10.9770/jesi.2021.8.3(11)

public procurement are needed to be evaluated by the specific approaches and methodologies. We will be able to ensure the sustainability of the healthcare system in the context of demographic aging processes in a line with the sustainability of public finances only in this way.

\section{Conclusions}

The processes of demographic aging and the associated changes in the mortality and morbidity structure of the diagnoses in the individual countries place ever-increasing demands on the healthcare systems. Fulfilling satisfaction of the health needs of the population is also closely related to the funding processes, an innovative and technological development as well as the overall setting of the healthcare policies in the individual countries. In the recent years, the health systems have been looking for savings and transparency of resources spent on the services performed. Public procurement plays an important role in this process. It is a strategic tool that every European Union member state possesses in the system of economic policy instruments. The basis of public procurement is an open competition in order to achieve the most efficient use of the public funds. Public procurement in the Slovak healthcare system has long been one of the most criticised processes by national as well as international institutions. In particular, an insufficient coordination between the involved institutions, an incorrectly set procedures, the inefficient public procurement processes and a poor applicability of the law are criticised often. The parameter "lowest price" results in the procurement of the products that are often of very low quality, which in turn causes a low quality of treatment. Successively, the low quality of treatment can also endanger the patient's health. The aim of our study was to evaluate the efficiency of the public procurement processes for medical equipment in Slovakia for the period of the years 2014 to 2019. The results of our study clearly pointed out that the number of offers has positive impact on creation of savings in public procurement process. We also document the evidence of amelioration of the procurement process over time in the context of savings generation. According to our results, NUTS level has also impact on savings in context of the public procurement. We document that public procurements done on the lower level of territorial administration reach higher savings. Contrary, if the public procurement is done on national level, the savings are significantly lower. Our study also points out that procurement method used in public procurement process influence the savings. Competitive procedure with negotiation create higher savings if compared to Tenders. The results of the analyses represent a valuable platform for the creators of strategic national healthcare plans as well as for the creation of concepts and methodologies enabling the improvement of public procurement processes in the healthcare system. The efficient public procurement processes in the healthcare system have to guarantee a higher quality of healthcare provided. Public procurement in the healthcare system should increase patient value and ensure the sustainability of the healthcare system as well as public finances from a macroeconomic point of view.

\section{References}

Baldi, S.; Vannoni, D. (2017). The impact of centralization on pharmaceutical procurement prices: The role of institutional quality and corruption. Regional Studies, 51(3), 426-438. https://doi.org/10.1080/00343404.2015.1101517 [Taylor \& Francis Online], [Web of Science ${ }^{\circledR}$ ], [Google Scholar]

Bem, A.; Siedlecki, R.; Predkiewicz, P.; Gazzola, P.; Ryszawska, B.; Ucieklak-Jez, P. (2019). Hospitals' Financial Health in Rural and Urban Areas in Poland: Does It Ensure Sustainability? Sustainability, 11(7), 1932. https://doi.org/10.3390/su11071932

Berezin, A.; Bruno, S. Sergi; Gorodnova, N. (2018). Efficiency Assessment of Public-Private Partnership (PPP) Projects: The Case of Russia. Sustainability, 10(10), 3713. https://doi.org/10.3390/su10103713

Borowiec, A. (2017). The impact of public procurement system on the development of competition in the economy in the light of empirical research. Oeconomia Copernicana, 8(1), 37-50. https://doi.org/10.24136/oc.v8i1.3 


\section{ENTREPRENEURSHIP AND SUSTAINABILITY ISSUES}

ISSN 2345-0282 (online) http://jssidoi.org/jesi/

2021 Volume 8 Number 3 (March)

http://doi.org/10.9770/jesi.2021.8.3(11)

Breandle, T.; Colombier, C. What drives public health care expenditure growth? Evidence from Swiss cantons, 1970-2012. Health Policy 2016, 120(9), 1051-1060. https://doi.org/10.1016/j.healthpol.2016.07.009

Briestenský, R.; Ključnikov, A. (2019). Identification of key factors of success of hospital management in Slovakia. Adiktologie 2019, 4.

Coviello, D.; Mariniello, M. (2014). Publicity requirements in public procurement: Evidence from a regression discontinuity design. Journal of Public Economics, 109, 76-100. https://doi.org/10.1016/j.jpubeco.2013.10.008

Dančíková, Z., Zachar, D. (2012). Analýza verejného obstarávania nemocníc v rokoch 2009-2012: Intenzita sút’ǎe v tendroch je nízka (Analysis of public procurement of hospitals in 2009-2012: The intensity of competition in tenders is low). Transparency International Slovakia/INEKO, 27.

European Commission. (2017). Za fungujúce a prínosné verejné obstarávanie v Európe. Oznámenie komisie Európskemu parlamentu, rade, európskemu a sociálnemu výboru a výboru regiónov (For functioning and rewarding public procurement in Europe. Communication from the Commission to the European Parliament, the Council, the European and Social Committee and the Committee of the Regions), 2017. Available online: https://eur-lex.europa.eu/legal-content/SK/TXT/HTML/?uri=CELEX:52017DC0572\&from=EN

European Commission. (2020) Systémy zdravotnej starostlivosti. Available online:

https://ec.europa.eu/info/sites/info/files/file_import/european-semester_thematic-factsheet_health-systems_sk.pdf

Fazekas, M., \& Tóth, I. J. (2016). From corruption to state capture: A new analytical framework with empirical applications from Hungary. Political Research Quarterly, 69(2), 320-334. https://doi.org/10.1177/1065912916639137

Fervarda, J.; Deleanu, J.; Unger, B. (2017). Corruption in public procurement: Finding the right indicators. European Journal of Criminal Policy Research, 23(2), 245-267. https://doi.org/10.1007/s10610-016-9312-3

Fuentes-Bargues, J. L.; Ferrer-Gisbert, P.S.; González-Cruz, M.C. Analysis of Green Public Procurement of Works by Spanish Public Universities. Int. J. Environ. Res. Public Health 2018, 15, 1888.

Grega, M. (2018). Možnosti zvýšenia efektívnosti verejného obstarávania v SR (Possibilities of increasing the efficiency of public procurement in the Slovak Republic). Disertační práce. Banská Bystrica: Ekonomická fakulta UMB 2018.

Grega, M.; Orviska, M.; Nemec, J.; Lawson, C. (2019). Factors Determining the Efficiency of Slovak Public Procurement. The NISPAcee Journal of Public Administration and Policy, 12(1), 43-68. https://doi.org/10.2478/nispa-2019-0002

Grzeszczyk, T. A.; Czajkowski, B. EU-funded Project Management in the Context of Suppliers and Contractors Selection. Procedia Engineering volume 2017, 182, 241-246. https://doi.org/10.1016/j.proeng.2017.03.181

Grzyl, B.; Apollo, M.; Miszewska-Urbańska, E.; Kristowski, A. The criteria for evaluation and selection the best tender applied by the authorities in Poland and selected EU countries. MATEC Web of Conferences 2018, 219, 04006. https://doi.org/10.1051/matecconf/201821904006

Grzyl, B.; Siemasko, A. The Life Cycle Assessment and Life Cycle Cost in public works contracts. 10th Conference on Interdisciplinary Problems in Environmental Protection and Engineering EKO-DOK 2018, 44, 00047.

Huculová, E. (2018). Porovnanie vybraných metodologických prístupov HTA na národnej úrovni a na úrovni nemocníc (Comparison of selected methodological approaches of HTA at the national level and at the hospital level). Exclusive journal: economy and society and environment, 6(4), 53-59.

Kiselova Bilekova, B.; Gavurova, B.; Rogalewicz, V. (2018). Application of the HTA Core Model for complex evaluation of the effectiveness and quality of Radium-223 treatment in patients with metastatic castration resistant prostate cancer. Health Econ Rev, 8, 27. https://doi.org/10.1186/s13561-018-0211-9

Kočišová, K.; Sopko, J. (2019). Key Indicators and Determinants in the Context of the Financial Aspects of Health Systems in Selected Countries. Adiktologie, 4. doi 10.35198/01-2019-004-0003. 


\section{ENTREPRENEURSHIP AND SUSTAINABILITY ISSUES}

ISSN 2345-0282 (online) http://jssidoi.org/jesi/

2021 Volume 8 Number 3 (March)

http://doi.org/10.9770/jesi.2021.8.3(11)

Kozik, R.; Karasiska-Jakowiec, I. Protecting the Environment Through Public Procurement Law - The Case of Poland. IOP Conference Series: Earth and Environmental Science 2016, 44(5), 052055.

Megyesiova, S.; Lieskovska, V. (2018). Analysis of the Sustainable Development Indicators in the OECD Countries. Sustainability, 10(12), 4554. https://doi.org/10.3390/su10124554

Megyesiova, S.; Lieskovska, V. (2019). Premature Mortality for Chronic Diseases in the EU Member States. International Journal of Environmental Research and Public Health, 16(20), 4021. https://doi.org/10.3390/ijerph16204021

Mudyarabikwa, O., Tobi, P., Regmi, K. (2017). Public-private partnerships to improve primary healthcare surgeries: clarifying assumptions about the role of private provider activities. Primary Health Care Research \& Development, 18, 366-375. https://doi.org/10.1017/S1463423617000147

Nemec, J.; Grega, M.; Horehájová, M.; Kubák, M. (2020). Efficiency of Public Procurement in the Slovak Health care. Český finanční a účetní časopis, 1, 27-39. https://doi.org/10.18267/j.cfuc.542

Nemec, J.; Grega, M.; Kubak, M. (2020). Vplyv miery konkurencie na výslednú cenu: verejné obstarávanie v slovenskom zdravotníctve (Influence of the degree of competition on the final price: public procurement in the Slovak healthcare system). Journal of Global Science, $5(2), 1-8$.

Ochrana, F.; Maaytová, A. (2012). Starting points for creating a transparent and non-corruption public procurement system. Ekonomický časopis, 60(7), 732-745.

Ochrana, F.; Pavel, J. (2013). Analysis of the impact of transparency, corruption, openness in competition and tender procedures on public procurement in the Czech Republic. Central European Journal of Public Policy, 7(2), 114-134.

Oruezabala, G.; Rico, J. C. (2012). The impact of sustainable public procurement on supplier management — The case of French public hospitals. Industrial Marketing Management, 41(4), 573-580. https://doi.org/10.1016/j.indmarman.2012.04.004

Petruželka, B.; Barták, M. (2019). Potential Indicators for the Analysis of the Association between Public Health and Drug Market Policing in the Czech Republic: Review of Public Health Indicators. Adiktologie, 19(1-2), 135-143. https://doi.org/doi/10.35198/01-2019-003-0001

Plaček M.; Nemec J.; Ochrana F.; Schmidt M.; Půček M. (2020). Analysis of Factors of Overpricing in Public Procurement: A Study for Low-Performing EU Countries. In: Farazmand A. (eds) Global Encyclopedia of Public Administration, Public Policy, and Governance. Springer, Cham. https://doi.org/10.1007/978-3-319-31816-5_3909-1

Predkiewicz, P.; Bem, A.; Ucieklak-Jez, P.; Siedlecki, R. (2019). Public or Private? Which Source of Financing Helps to Achieve Higher Health System Efficiency? Contemporary Trends and Challenges in Finance. Springer Proceedings in Business and Economics 2019. Ed. Jajuga, K; LocarekJunge, H; Orlowski, LT; Staehr, K. 2019, 191-199. https://doi.org/10.1007/978-3-030-15581-0_18

SK+MED (2020). Stanovisko k problematike verejného obstarávania medicínskych technológií a zdravotníckych pomôcok (Opinion on the issue of public procurement of medical technologies and medical devices). Available online: http://www.skmed.sk/files/Tezy_VO.pdf

Stefko, R.; Gavurova, B.; Kocisova, K. (2018). Healthcare efficiency assessment using DEA analysis in the Slovak Republic. Health Economics Review, 8(1), 6. https://doi.org/10.1186/s13561-018-0191-9

Stefko, R.; Gavurova, B.; Korony, S. (2016). Efficiency Measurement in Healthcare Work Management Using Malmquist Indices. Polish Journal of Management Studies, 13(1), 168-180. https://doi.org/10.17512/pims.2016.13.1.16

Šumpíková, M.; Ďurčeková, I. Transaction Costs, Outsourcing, and the Public Procurement Review Process in the Czech Republic and Slovakia. NISPAcee Journal of Public Administration and Policy 2019, 12(2), 233-250. https://doi.org/10.2478/nispa-2019-0021

Triantafillou, P. (2007). Benchmarking in the public sector: a critical conceptual framework. Public Administration Journal, 85(3), 829846. https://doi.org/10.1111/j.1467-9299.2007.00669.x

Ucieklak-Jez, P.; Bem, A. (2020). Does "Rural" Always Mean the Same? Macrosocial Determinants of Rural Populations' Health in Poland. International Journal of Environmental Research and Public Health, 17(2), 397. https://doi.org/10.3390/ijerph17020397 
Ucieklak-Jez, P.; Bem, A.; Siedlecki, R.; Predkiewicz, P. (2018). Concentration of Hospital Infrastructural Resources as a Source of Inequalities in Access to Health Care Benefits in Poland. Finance and Sustainability. Ed. Bem, A; Daszynska Zygadlo, K; Hajdikova, T; Juhasz, P. Springer Proceedings in Business and Economics, 1-10. https://doi.org/10.1007/978-3-319-92228-7_1

Vasconcelos, V.V. (2021). Social justice and sustainable regional development: reflections on discourse and practice in public policies and public budget. Insights into Regional Development, 3(1), 10-28. https://doi.org/10.9770/IRD.2021.3.1(1)

Weszl, M.; Rencz, F.; Brodszky, V. Is the trend of increasing use of patient-reported outcome measures in medical device studies the sign of shift towards value-based purchasing in Europe? The European Journal of Health Economics 2019, 20 (Suppl 1): S133-S140. https://doi.org/10.1007/s10198-019-01070-1

Zavadil, M.; Rogalewicz, V.; Vaclavikova, A.; Gavurova, B.; Bilan, S. (2020). Application on HB-HTA Methods in an Economic Quantification of Processes Covering Laboratory Technology in Hospitals. Transformations in Business \& Economics, 19(1).

\section{Acknowledgements}

This research was supported by the Internal Grant Agency of FaME Tomas Bata University in Zlin: RVO/2020: "Economic quantification of marketing processes that focus on value increase for a patient in a process of system creation to measure and control efficiency in health facilities in the Czech Republic".
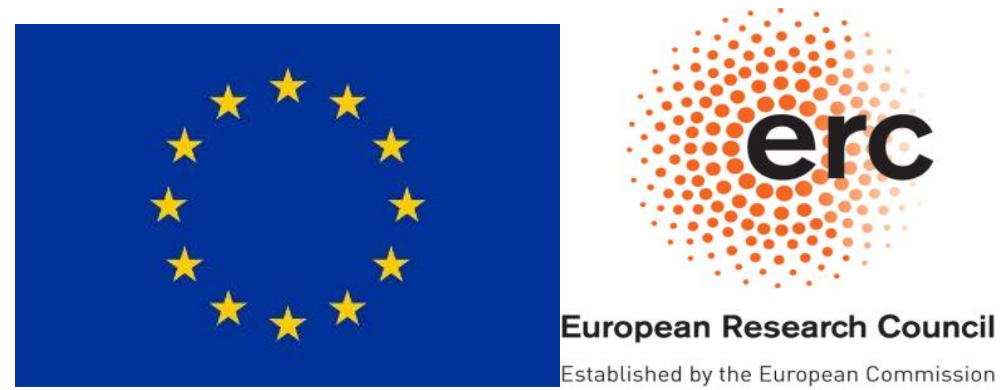

Beata GAVUROVA

ORCID ID: https://orcid.org/0000-0002-0606-879X

Matus KUBAK

ORCID ID: https://orcid.org/0000-0003-1438-479X

Make your research more visible, join the Twitter account of ENTREPRENEURSHIP AND SUSTAINABILITY ISSUES: @Entrepr69728810

Copyright (C) 2021 by author(s) and VsI Entrepreneurship and Sustainability Center

This work is licensed under the Creative Commons Attribution International License (CC BY).

http://creativecommons.org/licenses/by/4.0/

(c) (i) Open Access 